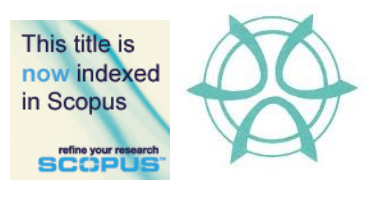

PLANNING MALAYSIA:

Journal of the Malaysian Institute of Planners

VOLUME 16 ISSUE 1 (2018), Page 251 - 264

\title{
MEDIATION EFFECT OF SOCIAL ASPECT IN THE RELATIONSHIP BETWEEN ENVIRONMENTAL AND ECONOMIC ASPECTS: THEIR INFLUENCE ON THE VALUE OF GREEN COMMERCIAL OFFICE PROPERTY
}

\author{
Tuti Haryati Jasimin ${ }^{1}$ \\ ${ }^{1}$ Razak School of Engineering and Advanced Technology \\ UNIVERSITI TEKNOLOGI MALAYSIA
}

\begin{abstract}
The potential value of green buildings is generally attributed to attractiveness for occupiers due to the environmental aspect which brings an impact to the social action, which eventually influences the economic aspect. These three aspects of sustainability (environment, social and economic), which adopted from Concentric Ring model contained various attributes. These attributes may or may not have significant influence among them, thus act as an indicator in impacting the green commercial office building's value. Accordingly, it is substantial to identify which attributes of green commercial office property have significant relationship of sustainability and to what level of influence among them, including the role of social aspect as a mediator between environment and economic aspects of sustainability. In order to analyse the hypothesized relationships, this study collects quantitative data from the property holders and also end users (tenants and owner-users) of green commercial office building, as they experience the benefits of sustainability in the building. Data were analysed using confirmatory factor analysis (CFA) with IBM SPSS Statistics 20.0 and AMOS 19.0, respectively. The results show that all hypothesized relationships between environmental, social and economic aspects were supported and indicated significant relationships among them, hence become a fundamental of green commercial office property valuation framework development.
\end{abstract}

Keyword: sustainability aspects, green commercial office building, Structural Equation Modelling (SEM), AMOS, valuation 
Tuti Haryati Jasimin

Mediation Effect of Social Aspect in the Relationship Between Environmental and Economic Aspects: Their Influence on the

Value of Green Commercial Office Property

\section{INTRODUCTION}

Sustainability aspects which consist of environment, social and economy, were recognized globally as among the factors that affect green property and potentially its value. They contain various attributes that may or may not have significant influence among them, thus act as indicators in impacting the green commercial office building's value. Therefore, it is critically prominent to distinguish which attributes of the green commercial office building have significant relationship of sustainability and to what degree of influence among them.

As green features study, which underlying the principle of sustainability consists of environment, social and economic aspects for property valuation purpose has yet to be conducted and practiced in Malaysia (Rahman, 2011; Lojuntin, 2014), it is significant to determine which factors and their attributes under the sustainability concept need to be addressed according to the hierarchy of importance based on Malaysian property market context. Accordingly, this research has utilized an internationally recognized green factors and their attributes for green commercial office property. However, the applicability of globally established features needs to be revised and tailored to Malaysian situation context, as according to RICS (2009), there are inconsistencies between the currently available metrics worldwide.

The globally recognized factors and attributes of green commercial office property are bound with several limitations like differences in geographical area (MD Darus \& Hashim, 2012), water scarcity and variation in market uptake of sustainability (Runde \& Thoyre, 2010; Babawale \& Oyalowo, 2011). They are also strongly depends on regional and local market conditions, the property type, conventions and applied valuation method (Lützkendorf \& Lorenz, 2011). Different rating system approaches also need to be considered due to the need to reflect local sustainability issues, environmental conditions (Ting, 2012) and also climate conditions (Samari, Ghodrati, Esmaeilifar, Olfat, \& Shafiei, 2013). The differences between rating system approaches were based on certain criteria including launch date, rating scales, information gathering, assessment, third party validation, certification and labelling, update process, governance, required qualification of assessors, weightings for the criteria, different climate zones, and the lack of flexibility of the systems to be applied in other countries. Other limitations are due to the different building codes or building regulation standards that differ from country to country, the buildings types, application of government guidelines, sustainability measures range and the timing of the certification in a building's life cycle.

In addressing these limitations and due to the inadequate evidence of data into sales and lease transactions for green commercial office property that exhibit green features in Malaysia (Wan Ismail, \& Abdul Majid, 2014), it is an essential for this research to identify the rank of importance of globally recognized green 
factors and their attributes that affecting the commercial office property value. Several scholars have suggested that it should be obtained from the view point of the market players, namely occupiers, as they experience the benefits of sustainability in the building (Hemphill, Mcgreal, \& Berry, 2002; Boyd, 2005; Myers, Reed, \& Robison, 2007).

Thorough exploration is required leading to a clearer identification of the relationship among the factors and attributes of sustainability aspects for commercial office building in order to distinguish the extent of influence among themselves. This in turn will be incorporated into valuation exercise, as sustainability has a multiple relationship among their various variables that affecting the value (Lorenz, \& Lützkendorf, 2008; Sayce, Sundberg, \& Clements, 2010).

\section{LITERATURE REVIEW}

The connection between sustainability and its impact upon a building's market value is increasingly important to the investment community. Investors and occupiers need to know the extent to which sustainability is impacting property worth if they were to respond effectively to sustainability issues (Sayce \& Ellison, 2003). This will require an analysis of how the market value is determined for green commercial office buildings. World Green Building Council (2013) in their report reveals that green buildings attract a financial premium in terms of rental and sales values through economic, environmental and social aspects.

\section{Economic Aspect}

The uptake of sustainability and sustainable practices in buildings would be accelerated if investors understood their direct impact on the value of property and portfolios. This is because the ownership of sustainable building results in multiple benefits to investors due to the various characteristics of such properties, ranging from lower operating costs to improved marketability, longer useful life spans, increased occupant productivity and well-being, as well as more stable cash-flows. As a result, economically quantifiable benefits (Kats, Alevantis, Berman, Mills, \& Perlman, 2003) can be obtained through ease of sale and rent, high tenant retention and higher occupancy rates, which result in higher achievable rents and the potential of increasing the value of the property, and higher relative investment returns (Bowman \& Wills, 2008).

The financial benefits of energy savings through reduced energy and water use, and waste reduction can be measured fairly precisely by using the energy performance certification, which specifies the total energy-related operating costs. This will lead to lower long-term operations and maintenance costs, and more efficient asset management and marketing advantage. A tenant with a net lease who rents space in a sustainable commercial building, with associated savings in operating costs, may be willing to pay a higher rent per 
Tuti Haryati Jasimin

Mediation Effect of Social Aspect in the Relationship Between Environmental and Economic Aspects: Their Influence on the

Value of Green Commercial Office Property

square meter if the tenant could identify long-term savings (Addae-dapaah, Hiang, \& Yen, 2009).

Sustainable buildings should have a longer economic life due to less depreciation and lower volatility in market value due to less environmental and marketability risks, which logically result in lower capitalization and discount rates. Sustainability features have the ability, in varying degrees, to slow depreciation and obsolescence (especially physical, functional and/or economic obsolescence) in a commercial building over the long term. This leads to reduced risk premiums.

\section{Social Aspect}

The intangible factors that are often cited on the social side appear to support a positive relation between green workplaces and worker satisfaction, which can lead to higher staff retention, reduced absenteeism and better health (Heerwagen, 2000), and consequently resulted in the increased worth of an office building (Robinson, 2005). Based on the Office Tenant Survey by Colliers International, it was found that major companies perceived green buildings to offer not only cost savings through reduced energy consumption but also benefits such as increased productivity, decreased employee turnover, less sick leave and better morale (Blundell, 2010). These positive benefits of green buildings are frequently being emphasized as important justifications for a firm's shift to a green workplace.

Miller and Buys (2008) report that respondents in their research felt that to be located in a sustainable building would help staff morale and public perceptions. Through sustainability, companies can improve their competitive advantage in the recruitment and retention of talents. This is because health and comfort are becoming increasingly important with the growing concern about staff welfare. An extensive research conducted by Kumar and Fisk (2002) has claimed strong correlations between sustainable design features (e.g. natural lighting, thermal comfort, air quality, worker-controlled temperature and ventilation, etc.) and reduced illness symptoms, reduced absenteeism and significant increase in the measured productivity of the workforce.

\section{Environmental Aspect}

Sustainable buildings offer a lower level of environmental risk by helping to minimize the environmental footprint of the real estate industry on the environment. A longer building life cycle and a healthy environment for occupants are found to be some of the attributes commonly promoted as positive characteristics of a sustainable building (Ang \& Wilkinson, 2008).

The sustainable attributes as highlighted by Schumann (2010) in the valuation process include location quality, competition analysis, building quality, architectural design, functionality, flexibility, and adaptability, user comfort, 
infrastructure, quality of construction materials with regard to environmental/health, energy consumption, quality of building services, water and waste water consumption, indoor air quality, and transport costs. Other sustainable attributes also include usability by third parties, impact of subject site on neighbourhood, supply and demand of sustainable properties, analysis of current rent payment, analysis of operating costs and also any other valueinfluencing factors.

Haynes (2007) in Miller, Pogue, Gough and Davis (2009) established a model by incorporating seven distinct components to represent the concept of office productivity with the dimensions of both the physical and behavioural environment as follows:

1. Distraction (interruptions, crowding, noise, privacy, overall atmosphere)

2. Environmental services (ventilation, heating, natural lighting, artificial lighting)

3. Office layout (personal storage, general storage, work area, desk, overall office layout, position of colleagues, circulation space.

4. Interaction (social interaction, work interaction, physical security, creative physical environment)

5. Designated areas (informal meeting areas, formal meeting areas, quiet areas)

6. Comfort (decor, cleanliness, overall comfort)

7. Informal interaction points (position of equipment, refreshment areas)

\section{DATA ANALYSIS}

There were two stages of analysis: (a) CFA using IBM SPSS Version 20.0 and (b) SEM using AMOS 19.0.

Stage 1. The responses to the questionnaire were initially entered into the IBM SPSS Version 20.0 in order to conduct the CFA procedure. Prior to modelling the interrelationship between latent constructs in a SEM, the CFA should be conducted first in order to confirm their unidimensionality, validity and reliability. The unidimensionality assessment should be conducted first prior to assessing the validity and reliability (Zainudin, 2015).

In order to determine how fit is the model to the data in hand, there are several Fitness Indexes in SEM that should be fulfilled. There are three categories of model fit namely Absolute Fit, Incremental Fit and Parsimonious Fit (Zainudin, 2015). Zainudin (2015) also suggests the use of at least one fitness index from each category of model fit. The information concerning the model fit category, their level of acceptance and comments are shown in Table 1. 
Tuti Haryati Jasimin

Mediation Effect of Social Aspect in the Relationship Between Environmental and Economic Aspects: Their Influence on the

Value of Green Commercial Office Property

Table 1: The three categories of model fit and their level of acceptance

\begin{tabular}{lll}
\hline Name of category & Name of index & Level of acceptance \\
\hline Absolute fit & Chi-square & P-value $>0.05$. Not applicable for large \\
& & sample size (more than 200) \\
& RMSEA & RMSEA $<0.08$ \\
& GFI & GFI $>0.90$ \\
Incremental fit & AGFI & AGFI $>0.90$ \\
& CFI & CFI $>0.90$ \\
& TLI & TLI $>0.90$ \\
Parsimonious fit & Chi-sq/df & NFI $>0.90$ \\
\hline Source: Tuti (2016) & & Chi-sq $/ \mathrm{df}<3.0$
\end{tabular}

Stage 2. Since this study is a confirmatory research type with the development of a model with some underlying theory, SEM was employed during the analysis process. Therefore, after the issues of unidimensionality, validity and reliability have been addressed, the significant effects among environmental, social and economic factors and their attributes of green commercial office building were analysed through the development of structural model using SEM.

\section{RESULTS}

\section{CFA}

Table 2 indicates that all the standardized factor loading estimates for all three main constructs ranged from .69 to .99 , exceeding the cutoff value of .05 unless item 8 and item 9 under main construct of environment. Both items were deleted due to low factor loading of less than .05. It resulting a new number of items for a total 49 measuring items. The AVE and CR estimates for all dimensions or sub constructs were above the cutoff value of .50 and .06 respectively.

Table 2: The CR and AVE for the all sub constructs in the model

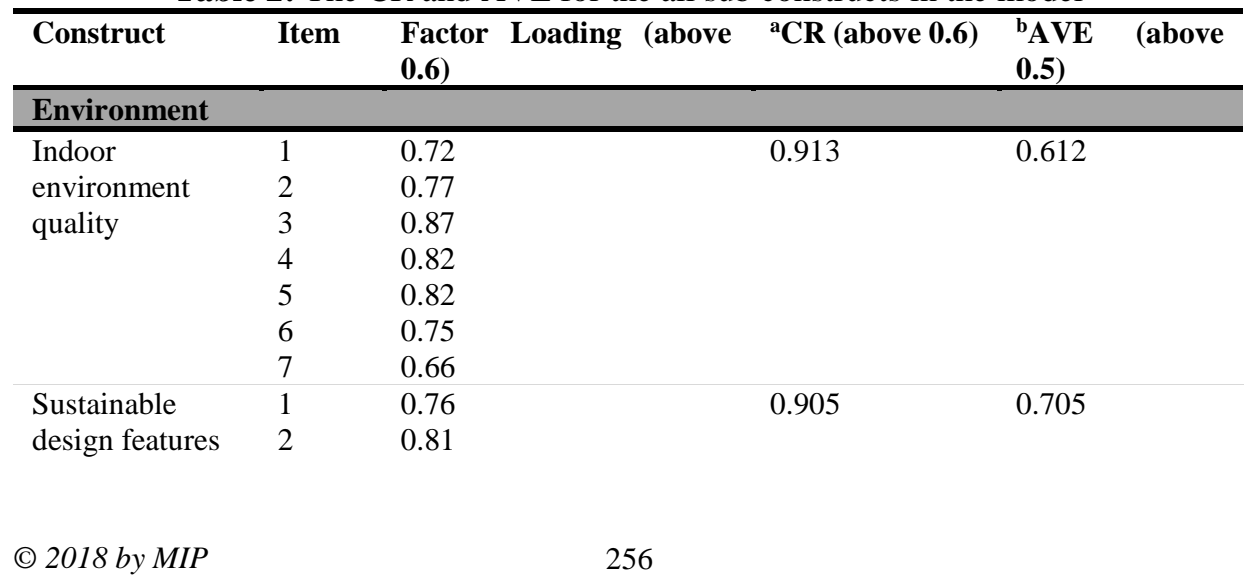


Journal of the Malaysia Institute of Planners (2018)

\begin{tabular}{|c|c|c|c|c|}
\hline & 3 & $\begin{array}{l}0.88 \\
0.90\end{array}$ & & \\
\hline \multirow{4}{*}{$\begin{array}{l}\text { Operational } \\
\text { expenditure }\end{array}$} & 1 & 0.86 & 0.783 & 0.633 \\
\hline & 2 & 0.86 & & \\
\hline & 3 & 0.76 & & \\
\hline & 4 & 0.69 & & \\
\hline \multirow{4}{*}{$\begin{array}{l}\text { Material and } \\
\text { resources }\end{array}$} & 1 & 0.81 & 0.888 & 0.664 \\
\hline & 2 & 0.82 & & \\
\hline & 3 & 0.80 & & \\
\hline & 4 & 0.83 & & \\
\hline \multirow[t]{2}{*}{ Transportation } & 1 & 0.90 & 0.934 & 0.875 \\
\hline & 2 & 0.97 & & \\
\hline \multirow{2}{*}{$\begin{array}{l}\text { Locational } \\
\text { factor }\end{array}$} & 1 & 0.74 & 0.732 & 0.588 \\
\hline & 2 & 0.78 & & \\
\hline \multirow{2}{*}{$\begin{array}{l}\text { Air quality } \\
\text { control }\end{array}$} & 1 & 0.83 & 0.816 & 0.689 \\
\hline & 2 & 0.83 & & \\
\hline \multicolumn{5}{|l|}{ Social } \\
\hline \multirow[t]{5}{*}{ Productivity } & 1 & 0.76 & 0.851 & 0.544 \\
\hline & 2 & 0.69 & & \\
\hline & 3 & 0.78 & & \\
\hline & 4 & 0.70 & & \\
\hline & 5 & 0.72 & & \\
\hline \multirow{4}{*}{$\begin{array}{l}\text { Occupants' } \\
\text { satisfaction and } \\
\text { well-being }\end{array}$} & 1 & 0.76 & 0.883 & 0.853 \\
\hline & 2 & 0.81 & & \\
\hline & 3 & 0.81 & & \\
\hline & 4 & 0.85 & & \\
\hline \multirow{4}{*}{$\begin{array}{l}\text { Marketing } \\
\text { advantage }\end{array}$} & 1 & 0.83 & 0.911 & 0.719 \\
\hline & 2 & 0.88 & & \\
\hline & 3 & 0.84 & & \\
\hline & 4 & 0.84 & & \\
\hline \multicolumn{5}{|l|}{ Economic } \\
\hline \multirow[t]{4}{*}{ Rental growth } & 1 & 0.93 & 0.900 & 0.694 \\
\hline & 2 & 0.87 & & \\
\hline & 3 & 0.78 & & \\
\hline & 4 & 0.74 & & \\
\hline \multirow[t]{5}{*}{ Cash flow } & 1 & 0.86 & 0.922 & 0.703 \\
\hline & 2 & 0.82 & & \\
\hline & 3 & 0.85 & & \\
\hline & 4 & 0.84 & & \\
\hline & 5 & 0.82 & & \\
\hline \multirow[t]{2}{*}{ Duration to sale } & 1 & 0.86 & 0.839 & 0.732 \\
\hline & 2 & 0.84 & & \\
\hline
\end{tabular}

Source: Tuti (2016)

Note. $\mathrm{AVE}=$ average variance extracted $\mathrm{CR}=$ construct reliability

${ }^{a} \mathrm{CR}: \frac{\left(\sum_{i=1}^{n} L_{i}\right)^{2}}{\left(\sum_{i=1}^{n} L_{i}\right)^{2}+\left(\sum_{i=1}^{n} e_{i}\right)}$ where $L_{i}$ represents the standardized factor loading of $i$ th items with a total of $n$ items. ei refers to the error variance of $i$ th term.

bAVE: $: \frac{\sum_{i=1}^{n} L_{i}^{2}}{n}, L_{i}$ where $\mathrm{L}_{\mathrm{i}}$ i represents the standardized factor loading $\mathrm{n}$ with $i$ th item with a total of $\mathrm{n}$ items. 
Tuti Haryati Jasimin

Mediation Effect of Social Aspect in the Relationship Between Environmental and Economic Aspects: Their Influence on the

Value of Green Commercial Office Property

\section{AMOS Output: The Unstandardized Estimate}

In unstandardized estimates, the results show the regression path coefficient or regression weights for the model in this study. This indicates the estimate of beta coefficient, which measures the effects of exogenous construct and mediator construct on the endogenous construct.

In order to explore the relationship among the main construct, together with their underlying factors and attributes, this study tested the main hypotheses as illustrated in Figure 1.

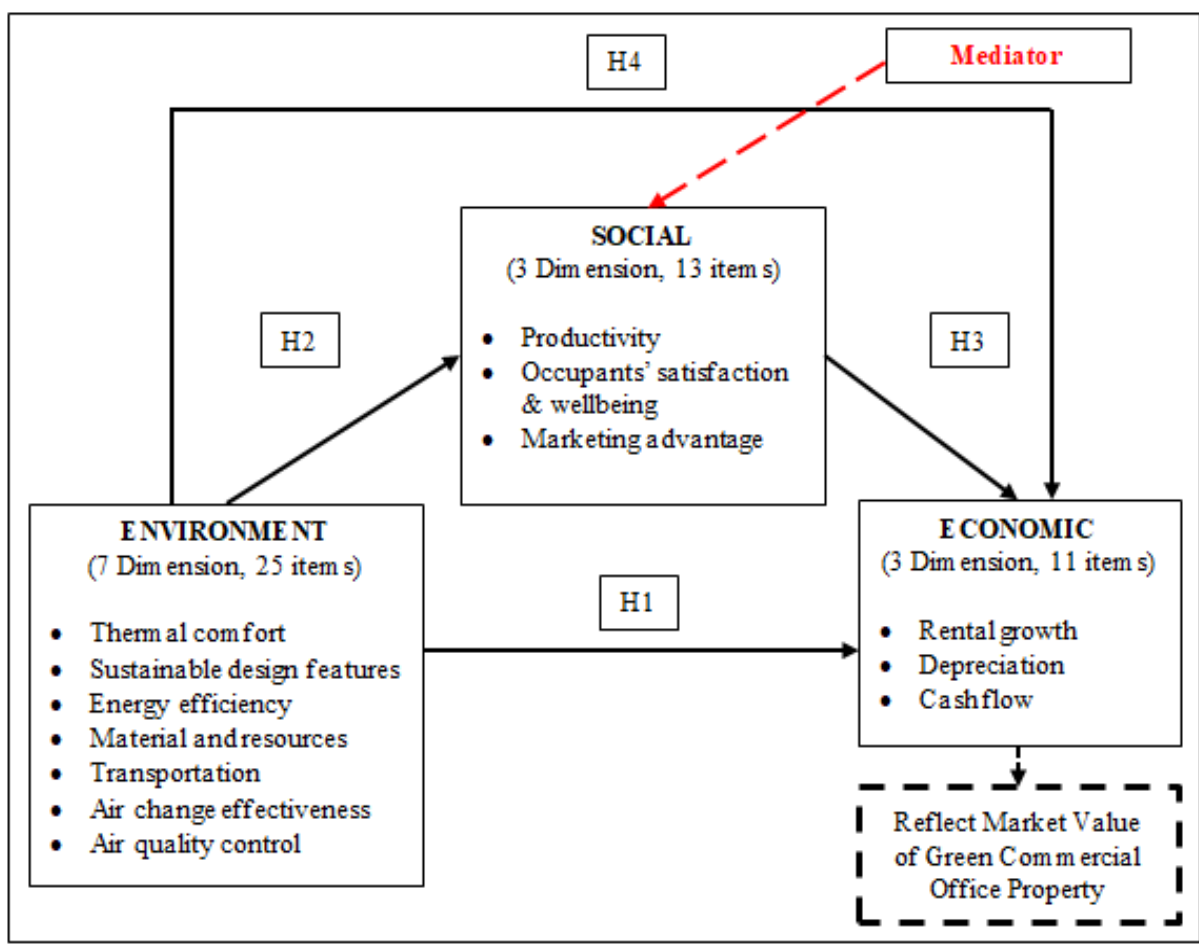

Figure 1: The hypothesized link under the respective hypothesis Source: Tuti (2016)

\section{DISCUSSION}

H1: Environmental Aspect Has a Significant and Direct Influence on Economic Aspect

The SEM analysis of the first hypothesis indicates that the environment aspect has a significant and direct influence on economic aspect (Table 3). 
PLANNING MALAYSIA

Journal of the Malaysia Institute of Planners (2018)

Table 3: The path analysis of SEM for Hypothesis 1

\begin{tabular}{lccccccc}
\hline Construct & Path & Construct & Estimate & S.E. & C.R. & $\begin{array}{l}\text { P- } \\
\text { Value }\end{array}$ & Result \\
\hline Economic & $<---$ & Environment & 0.543 & 0.152 & 3.582 & 0.001 & Significant \\
\hline Source: Tuti(2016) & & & & & &
\end{tabular}

The environmental aspect consisted of seven factors with 25 attributes underlying each factor, while the economic aspect consisted of three factors with 11 attributes underlying each factor. The results show that environmental factors and their attributes positively correlated to all economic factors and attributes. Similarly, RICS (2005) also find that the environmental factors and their related attributes positively correlated to economic aspect of sustainability. For instance, sustainable design feature has a theoretical linkage to value in terms of improved marketability, reduced ongoing maintenance cost, higher sales/rent, absorption and re-tenanting. Charles et al. (2004) reveal that certified "green" commercial buildings exhibit higher real-estate values, presumably reflecting expectations for reduced operating costs, and improved organizational productivity through better indoor environments for employees.

The factor of indoor environment quality (IEQ) through the attributes such as indoor air quality, thermal comfort, and reduction contribute to the reduction of risk, greater marketability, faster sales and let, and also resulting in higher net operating income (NOI) and return on investment (ROI) (RICS, 2005). Previous studies undertaken on certified green buildings have determined that a rental rate premium exists in many cases through lower operating costs and enhanced marketability. This is attributed to the attractiveness of green buildings to prospective tenants in terms of their superior indoor environment.

From valuation perspective, the locational characteristics of a property are some of the most important factors considered when assessing asset value potential (Brandon, 2009). The rationale for mentioning the importance of locational characteristics in this discussion is that it is extremely difficult to separate and quantify locational attributes from other property specifics when analysing value. Locational factor is often the greatest determinant in an investor's decision to purchase a particular property. A property's specific location relative to its competition, its access to major transportation arteries and public transport, and overall visibility are critical factors in assessing the marketability of a property.

\section{H2: Environmental Aspect Has a Significant and Direct Influence on Social Aspect}

The result of SEM analysis, as shown in Table 4, indicates that the second hypothesis of this study was supported. The hypothesis was environment aspect 
Tuti Haryati Jasimin

Mediation Effect of Social Aspect in the Relationship Between Environmental and Economic Aspects: Their Influence on the

Value of Green Commercial Office Property

has a significant and direct influence on social aspect. All factors and attributes of environment were found positively correlated with all three factors and 13 attributes of social aspect.

Table 4: The path analysis of SEM for Hypothesis 2

\begin{tabular}{llllllll}
\hline Construct & Path & Construct & Estimate & S.E. & C.R. & $\begin{array}{l}\text { P- } \\
\text { Value }\end{array}$ & Result \\
\hline Social & $<---$ & Environment & 1.062 & 0.142 & 7.466 & 0.001 & Significant \\
\hline Source: Tuti (2016) & & & & & &
\end{tabular}

Several studies have reported positive correlation between building's internal environment (e.g. ventilation, its indoor air quality, better lighting, natural light, clean and fresh air) and employee health and productivity (Wargocki, Wyon, Baik, Clausen, \& Fanger, 2004). Indoor environmental conditions affect the prevalence of several very common health effects. These health effects lead to health care costs plus the costs of sick leave and reduced performance during periods of illness (Fisk, 2000). Similarly, extensive research conducted by Kampschroer and Heerwagen (2005) identified strong correlations between sustainable design features (e.g. natural lighting, thermal comfort, air quality, worker-controlled temperature and ventilation, etc.) and reduced illness symptoms, reduced absenteeism and significantly increases of measured productivity of workforces. Meanwhile, World Green Building Council (2013) argues that green design attributes of buildings and indoor environments have social impacts on worker productivity and occupant health and well-being. These two elements of productivity and health benefit contribute to any added capital costs for green buildings, as well as any increases in market value or rental premium, which lies in the realization of occupancy-related benefit.

\section{H3: Social Aspect Has a Significant and Direct Influence on Economic Aspect}

The result of SEM analysis on the third hypothesis also shows that the hypothesis was supported (Table 5). Enormous cost savings are being made in 'soft benefits' such as increased productivity, better health and well-being, improved morale and reduced absenteeism. In commercial office buildings, employee overhead is the highest cost, thus improving their productivity and reducing turnover and absenteeism may be a green building's most significance economic performance indicator (Davies, 2010). Reed \& Wilkinson (2005) highlighted that increased staff productivity include lower staff absenteeism can be achieved in an energy efficient building and converted into a monetary saving. 
PLANNING MALAYSIA

Journal of the Malaysia Institute of Planners (2018)

Table 5: The path analysis of SEM for Hypothesis 3

\begin{tabular}{llllllll}
\hline Construct & Path & Construct & Estimate & S.E. & C.R. & $\begin{array}{l}\text { P- } \\
\text { Value }\end{array}$ & Result \\
\hline Economic & $<---$ & Social & 0.573 & 0.100 & 5.747 & 0.001 & Significant \\
\hline Source: Tuti (2016) & & & & & & &
\end{tabular}

The owner of green building can also find that its image is seen much more positively. This helps to attract and retain tenants, employees, clients and suppliers, and, arguably, make green buildings more attractive to owneroccupiers and shareholders (Davies, 2010).

H4: Social aspect mediates the relationship between environment aspect and economic aspect of green commercial office property.

The social aspect was considered as a mediating variable in this study. The goal of mediation analysis is to clarify the nature of the relationship between the independent variable (IV) and dependent variable (DV). The results of the analysis as depicted in Figure 2 show that social aspect does mediate the relationship between IV (environment aspect) and DV (economic aspect). The type of mediation is called 'Partial Mediation' since the direct effect of environment aspect on economic aspect is still significant after social aspect enters the model. In this case, even though environment aspect has a significant direct effect on the economic aspect, it has also a significant indirect effect on the economic aspect through the mediator variable namely social aspect.

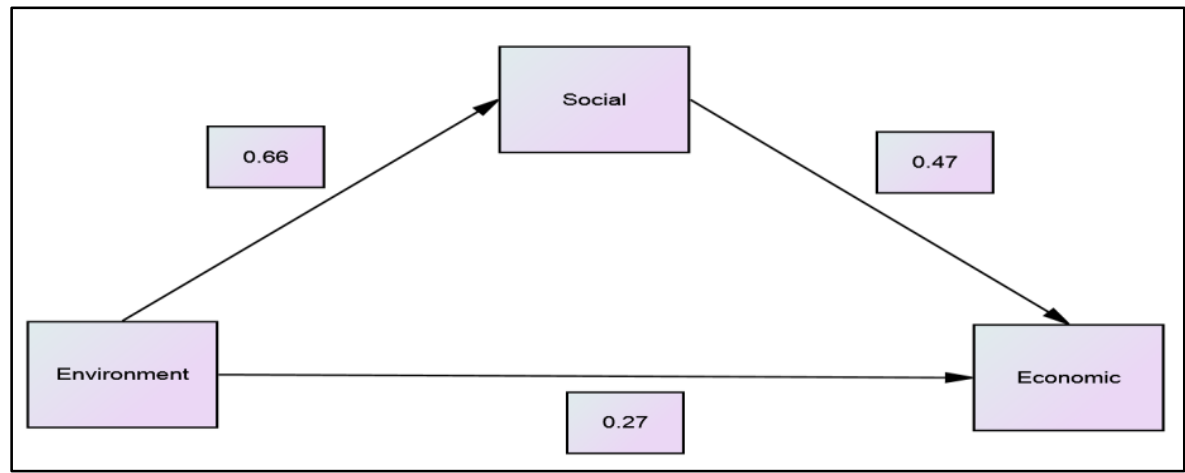

- $\quad$ The indirect effect $=0.66 \times 0.47=0.310$

- $\quad$ The direct effect 0.27

- $\quad$ The mediation occurs since indirect effect $>$ direct effect

- Therefore, the type of mediation is partially mediation since direct effect is still significant after the mediator enters the model

Figure 2: Testing for mediation effect in a model Source: Tuti (2016) 
Tuti Haryati Jasimin

Mediation Effect of Social Aspect in the Relationship Between Environmental and Economic Aspects: Their Influence on the

Value of Green Commercial Office Property

The concept of direct and indirect effect could be applied in the determination of green building's value. The value of green is defined as the net additional value obtainable by a green building in the market compared to conventional or non-green properties. The value is due to the financial benefits which are influenced by direct and indirect effects as argued by Lorenz \& Lützkendorf (2008).

\section{CONCLUSION}

The findings of this study have overwhelmingly pointed to green commercial office property enjoying various advantages, which translate as an attribute of the property. All of those 49 identified attributes, through a CFA analysis have been divided into 13 factors, which belong to sustainability aspects of environment, social and economic.

Through the identified factors and attributes of green commercial office property that affecting their value, this study has also managed to prove that there are significant relationships among the sustainability aspects, namely environment, social and economic. Therefore, it can be suggested that all of identified factors and attributes of green commercial office property might be incorporated into valuation exercise, as sustainability aspects have been proved to have a significant relationship among their various variables that affecting the value of green buildings.

\section{REFERENCES}

Addae-dapaah, K., Hiang, L. K., \& Yen, N. (2009). Sustainability of sustainable real property development. Journal of Sustainable Real Estate, 1(1), 203-225.

Ang, S. L., \& Wilkinson, S. J. (2008). Is the social agenda driving sustainable property development in Melbourne, Australia? Property Management, 26(5), 331-343.

Babawale, G. K., \& Oyalowo, B. A. (2011). Incorporating sustainability into real estate valuation: The perception of Nigerian valuers. Journal of Sustainable Development, 4(4), 236-249.

Blundell, L. (2010). Sustainability survives the GFC. Property Australia, 25(4), 44-46.

Bowman, R., \& Wills, J. (2008). Valuing green: How green buildings affect property values and getting the valuation method right. Green Building Council of Australia.

Boyd, T. (2005). Can we assess the worth of environmental and social characteristics in investment property? Retrieved from http://prres.net/Papers/Boyd_Assess_Environmental_Social_Characteristics_ Investment_Property.pdf

Brandon, S. (2009). High performance green building: What's it worth? Investigating the market value of high performance green buildings. Retrieved from https://livingfuture.org/wpcontent/uploads/2016/11/High_Performance_Green_Building.pdf 
Charles, K. E., Danforth, A. J., Veitch, J. A., Zwierzchowski, C., Johnson, B., \& Pero, K. (2004). Workstation design for organizational productivity. National Research Council Canada; Public Works and Government Services Canad

Davies, R. (2010). Green value - Green buildings, growing assets - A major collaboration into the study of building value by building green. Retrieved from https://www.hatchdesign.ca/wpcontent/uploads/2011/12/greenvaluereport1.pdf

Fisk, W. J. (2000). Health and productivity gains from better indoor environments and their relationship with building energy efficiency. Annual Review of Energy and the Environment, 25(1), 537-66.

Hemphill, L., Mcgreal, S., \& Berry, J. (2002). An aggregated weighting system for evaluating sustainable urban regeneration. Journal of Property Research, 19(4), 353-373.

Heerwagen, J. H. (2000). Green buildings, organizational success, and occupant productivity. Building Research \& Information, 28(5), 353-367.

Kats, G., Alevantis, L., Berman, A., Mills, E., \& Perlman, J. (2003). The costs and financial benefits of green buildings. A report to California's Sustainable Building Task Force. Sustainable Building Task Force.

Kampschroer, K., \& Heerwagen, J. H. (2005). The strategic workplace: Development and evaluation. Building Research \& Information, 33(4), 326-37.

Kumar, S., \& Fisk, W. (2002). The role of emerging energy-efficient technology in promoting workplace productivity and health: Final report. Retrieved from https://escholarship.org/uc/item/0sw558qr

Lorenz, D., \& Lützkendorf, T. (2008). Sustainability in property valuation: Theory and practice. Journal of Property Investment \& Finance, 26(6), 482-521.

Lützkendorf, T., \& Lorenz, D. (2011). Capturing sustainability-related information for property valuation. Building Research \& Information, 39(3), 256-273.

Lojuntin, S. A. (2014). Green construction industry; national and global challenges.

MD Darus, Z., \& Hashim, N. A. (2012). Sustainable building in Malaysia: The development of sustainable building rating system. In C. Ghenai (Ed.), Sustainable development - Education, business and management - Architecture and building construction - Agriculture and food security (pp. 113-144). InTech. Available from: http://www.intechopen.com/books/sustainabledevelopmenteducation-business-and-management-architecture-and-buildingconstruction-agriculture-and-foodsecurity/sustainable-building-in-malaysiathe-development-of-sustainable-building-rating-system

Miller, E., \& Buys, L. (2008). Retrofitting commercial office buildings for sustainability: Tenants' perspectives. Journal of Property Investment \& Finance, 26(6), 552561.

Miller, N., Pogue, D., Gough, Q., \& Davis, S. (2009) Green buildings and productivity. Journal of Sustainable Real Estate, 1(1), 65-89.

Myers, G., Reed, R., \& Robinson, J. (2007, January). The relationship between sustainability and the value of office buildings. In 13th Annual Pacific Rim Real Estate Conference, January 21-24, 2007, Fremantle, Western Australia.

Rahman, R. (2011, April 30). A green look at property value. The Star. 
Tuti Haryati Jasimin

Mediation Effect of Social Aspect in the Relationship Between Environmental and Economic Aspects: Their Influence on the

Value of Green Commercial Office Property

Reed, R. G., \& Wilkinson, S. J. (2005). The increasing importance of sustainability for building ownership. Journal of Corporate Real Estate, 7(4), 339-350.

RICS. (2005). Green value.

RICS. (2009). Sustainability and commercial property valuation. Westwood Business Park, London.

Robinson, J. (2005). Property valuation and analysis applied to environmentally sustainable development. Retrieved from http://cavrep.com.au/E/ENVIRONMENTALLY\%20SUSTAINABLE\%20 DEVELOPMENT\%20-\%20VALUATION.pdf

Runde, T. P., \& Thoyre, S. (2010). Integrating sustainability and green building into the appraisal process. Journal of Sustainable Real Estate, 2(1), 221-248.

Samari, M., Ghodrati, N., Esmaeilifar, R., Olfat, P., \& Mohd Shafiei, M. W. (2013). The investigation of the barriers in developing green building in Malaysia. Modern Applied Science, 7(2), 1-10.

Sayce, S., \& Ellison, L. (2003, August) Integrating sustainability into the appraisal of property worth: Identifying appropriate indicators of sustainability. In AREUEA conference, August 21-23, Skye, Scotland.

Sayce, S., Sundberg, A., \& Clements, B. (2010). Is sustainability reflected in commercial property prices: an analysis of the evidence base. London: RICS.

Schumann, B. (2010). Impact of sustainability on property values (Master's thesis). University of Regensburg.

Ting, K. H. (2012, April). Tropical green building rating systems: A comparison between Green Building Index and BCA Green Mark. In 2012 IEEE Business, Engineering \& Industrial Applications Colloquium (BEIAC), April 7-8, 2012, Kuala Lumpur, Malaysia.

Tuti, H. J. (2016). A model structure of sustainability aspects for green commercial office property valuation (Doctorate thesis). Universiti Teknologi Malaysia.

Wan Ismail, W. N., \& Abdul Majid, R. (2014, April). The impact of green features on property valuation procedure. In International Real Estate Research Symposium, April 29-30, 2014, Kuala Lumpur, Malaysia.

Wargocki, P., Wyon, D. P., Baik, Y. K., Clausen, G., \& Fanger, P. O. (2004). Perceived air quality, sick building syndrome (sbs) symptoms and productivity in an office with two different pollution loads. Indoor Air 9(3), 165-179.

World Green Building Council. (2013). The business case for green building.

Zainudin, A. (2015). SEM made simple: A gentle approach to learning structural equation modelling. MPWS Rich Publication. 